\title{
Beyond proximate and distal causes of land-use change: linking Individual motivations to deforestation in rural contexts
}

\author{
$\underline{\text { Ximena Rueda }}^{1}, \underline{\text { Maria Alejandra Velez }}^{1}, \underline{\text { Lina Moros }}^{1,2}$ and Luz Angela Rodriguez $^{3}$
}

\begin{abstract}
Most of the literature on the causes of tropical deforestation has focused on the proximate and distal causes. However, research exploring the psychological drivers of deforestation, i.e., motivations, is still scant despite being crucial to understand the processes of land-use change and individual decision making within social-ecological systems. We studied the combined effect of structural and individual causes of deforestation, with particular emphasis on motivations, for a sample of rural households in Colombia's foremost tropical deforestation frontier. We implemented a new instrument based on self-determination theory to measure five different types of motivations to protect the forests: intrinsic, guilt/regret, social, extrinsic motivations, and amotivation (lack of motivation). Our findings show that, controlling for the structural and household drivers widely identified in the deforestation literature, intrinsic motivations positively correlate with less self-reported deforestation. Also, amotivated people and those with extrinsic motives, such as expected payments for conservation, are more likely to deforest. Our results show that motivations can explain variation in land-use decisions and thus should be considered when designing, implementing, and evaluating conservation policies aiming to halt deforestation.
\end{abstract}

Key Words: agricultural expansion; Colombia; deforestation frontier; land-use change; motivations

\section{INTRODUCTION}

Tropical deforestation continues to be a major concern in the developing world. About 129 million ha of forest was lost between 1990 and 2015 mainly in the tropical regions of South America and Africa (Food and Agriculture Organization of the United Nations 2015). Identifying distal and proximate drivers of tropical deforestation has been one of the main concerns of the literature on land-use change (Kaimowitz and Angelsen 1998, Lambin et al. 2001, Geist and Lambin 2002, DeFries et al. 2010). Most of these studies focus on both the behavior of landholders and the structural processes that affect such behavior, based on objective or observable factors. These studies have explored the demographic, economic, institutional, and cultural factors that lead agents to clear forests (Geist and Lambin 2002). Such research has been developed at different scales: from the household or firm level to regional, national, and global scales, and using analytical, empirical, or simulation models (Kaimowitz and Angelsen 1998).

Although civic values and behavioral factors have been described as important drivers of deforestation (Geist and Lambin 2001), little systematic effort has been made to link motivations, i.e., the set of reasons to protect the forests, to the observed patterns of land-use change in tropical settings. Other fields of study, such as environmental psychology, have focused on understanding the relationship between proenvironmental motivations and behaviors, mostly in urban settings, e.g., car use, energy saving, and recycling. In general, this body of literature has established that both contextual and individual factors such as attitudes, motivations, goals, values, beliefs, concerns, and self-identity influence behaviors that benefit the environment (Steg and Vlek 2009). Also, the literature on environmental studies and policy has attempted to establish the effect of conservation programs on motivations (Rico García-Amado et al. 2013, Moros et al. 2017) and drivers of engagement in particular conservation practices or programs (Greiner et al. 2009, Souto et al. 2014, Greiner 2015,
Ruiz-Mallén et al. 2015). However, to our knowledge, no study has attempted to determine the interaction between proenvironmental motivations of rural dwellers and stated landuse change. Understanding baseline motivations of rural inhabitants and forest users is important given that the design of policy instruments aiming at reducing deforestation may have unintended effects on motivations, which, in turn, can affect conservation outcomes and behaviors (see, e.g., Rico GarcíaAmado et al. 2013, Moros et al. 2017).

We studied the effect of motivations on the stated decision to deforest for a group of farmers, controlling for individual and structural variables. We used the questionnaire designed by Moros et al. (2017), based on the self-determination theory (SDT) proposed by Ryan and Deci (2000), to explore the different types of motivations and their effect on the reported decision of farmers to deforest. Using a set of different types of motivations allows us to capture more precisely the specific reasons behind preserving forests and, as such, design and improve programs and policies suited to particular types of individuals. We applied a survey to a group of 64 farmers in the rural area of Florencia, the capital city of Caquetá, one of the regions with the highest rates of deforestation in Colombia. Our findings show that, controlling for socio-economic factors, intrinsic motivations negatively correlate with self-reported deforestation. That is, more intrinsically motivated individuals report less deforestation. Also, amotivated individuals are more likely to deforest, as well as people concerned with external motivations such as expected payments for conservation. Our findings contribute to the discussion of land-use change beyond the proximate and distal or underlying causes of deforestation usually considered in the literature. Although our empirical strategy does not allow us to claim causality, our results open an urgent and unexplored research agenda and raise considerations for the implementation of conservation policies, such as payment for ecosystems services, aimed at changing behavior. In particular, they highlight the

${ }^{1}$ School of Management, Universidad de los Andes, Bogotá, Colombia, ${ }^{2}$ Institute of Environmental Science and Technology (ICTA), Universitat Autònoma de Barcelona, ${ }^{3}$ School of Environmental and Rural Studies, Pontificia Universidad Javeriana, Bogotá, Colombia 
importance of considering the impacts on motivations when designing, implementing, and evaluating the effects of such types of policies to avoid possible crowding-out effects (Agrawal et al. 2015).

\section{LITERATURE REVIEW}

\section{Evolution of the drivers of land-use change}

There is a large body of literature that attempts to unravel the causes of land-use change (Turner et al. 2007). Original studies on tropical deforestation found population to be the main explanatory variable, either because of the so-called frontier theory, in which entrepreneurs and smallholders colonized the frontier in search of profitable economic activities, or because they were pushed out of the agricultural frontier and into marginal lands, i.e., the "immiseration" theory (Rudel and Roper 1997). When more variables were included, population started to lose its prominence as the main driver of deforestation, and other elements such as road building, state-sponsored development programs, and credit availability began to combine with population to explain deforestation in areas such as the Brazilian Amazon (Pfaff 1999).

The causes of deforestation have since been classified as direct or proximate and distal or underlying. According to Geist and Lambin (2002), proximate causes include local-level human activities such as agricultural expansion or infrastructure development that affect land-use decisions and, therefore, forest cover. Underlying driving forces are social processes, such as human population dynamics or agricultural policies that support the proximate causes. Underlying causes can operate at a local, national, or global level.

Empirical studies of drivers of deforestation have been summarized in two seminal meta-analyses (Kaimowitz and Angelsen 1998, Geist and Lambin 2002). Kaimowitz and Angelsen (1998) identify farm-level explanatory factors of deforestation, such as wages, availability of off-farm employment, and the price of agricultural inputs. As wages increase, off-farm employment is more abundant, and the price of agricultural inputs rises, as the pressure on forests decreases. Geist and Lambin (2002) separate the causes of deforestation into biophysical, technological or economic, institutional, demographic, and cultural. Their analysis shows that different combinations of proximate and underlying driving forces determine tropical forest decline worldwide (Lambin et al. 2001). The basic assumption of these studies is that land users behave like rational agents who respond to price incentives, given by the opportunity cost of deforestation. Within such models, only instrumental reasons guide land-use decisions. In some cases, other considerations, such as values and beliefs, are mentioned, but how they shape people's behaviors is not theorized (Geist and Lambin 2002).

More recent studies have reported that clearly established property rights are associated with less deforestation (Robinson et al. 2014). Additionally, because deforestation decisions depend on expected profits, neighborhood deforestation influences the probability of deforestation in a particular parcel. There are, therefore, patterns of spatial interactions in deforestation (Robalino and Pfaff 2012).

Drivers and patterns of deforestation also evolve over time because of changes in international markets, globalization, and urbanization. Thus, instead of focusing exclusively on the local causes of land change, newer streams of research have identified the importance of its distant drivers. Currently, the main agents of deforestation are private agricultural enterprises, i.e., wellcapitalized ranchers, farmers, and loggers, that have led the activity, in particular in Southeast Asia and the Amazon basin, to satisfy global markets (Rudel et al. 2009, DeFries et al. 2010). It is the demand for agricultural products in distant urban and international locations that is fueling current deforestation (Leblois et al. 2017). Globalization affects land-use change directly by increasing the opportunity cost of forested land. Also, the "geographies of trade" that interconnect distant socialecological systems cause leakage or indirect effects on land use within and across countries as a consequence of local or national interventions (Meyfroidt et al. 2013). For example, policies to promote sustainable land use in a specific site may have unintended effects by displacing land change to less regulated places. These studies focus on global-scale social processes that are shaping decisions on the land. Urbanization, for instance, increases the demand for agricultural commodities, such as vegetable oils, widely used in processed food. This demand is manifested in price transmission to local land users, increasing the profitability of soy or palm cultivation in tropical regions. Because the main agents of land change are companies and entrepreneurs, decision making is mainly related to extrinsic, profit-seeking motives. In some instances, reputational risks for branded companies might deter them from engaging in deforestation, either direct or indirectly through their providers, but the underlying motives are profit driven (Mayer and Gereffi 2010).

As the role of international markets becomes more prominent in explaining land transformation, agricultural intensification has been suggested as a strategy to reduce the use of forested land for agriculture while satisfying agricultural demand. However, empirical analysis has shown a weak or nonexistent relationship between intensification and land sparing for conservation (Phelps et al. 2013). Intensification can increase future agricultural land rents, which creates incentives to clear more land for agricultural expansion, particularly when driven by market pressures (Phalan et al. 2011, Byerlee et al. 2014, Carrasco et al. 2014). Thus, whether farmers have market outlets for their crops, especially in the international market, could be a significant driver of deforestation. All of these studies are based on the assumption that only extrinsic, instrumental reasons explain farmers' behavior toward deforestation. We take into account some of these variables to predict self-reported deforestation but add a more complex and wider array of motivations for engaging in deforestation in the forest frontier.

\section{Motivations and environmental behavior}

Although behavioral factors have been described as important in driving deforestation (Geist and Lambin 2001), little systematic effort has been made to link intrinsic motivations, i.e., the set of noninstrumental reasons to protect the forests, to the observed patterns of land-use change. One stream of literature, particularly in environmental psychology, has studied the role of values, beliefs, and attitudes to understand the determinants of urban proenvironmental behavior, e.g., energy saving, recycling, and composting. In addition, studies applied to rural contexts focus on the effect of attitudes on environmental practices and 
conservation behavior, but few efforts have been made to link such psychological aspects to land-use change, which is our objective.

Different theories are used to model the determinants of proenvironmental behavior (e.g., theory of reasoned action: Fishbein and Ajzen 1975; values-norms beliefs: Stern 2000; theory of planned behavior: Ajzen 1991, among others). We use SDT (Ryan and Deci 2000) as our framework because of its predictive power in explaining proenvironmental behaviors (Festré and Garrouste 2015). SDT, instead of conceiving motivations as a dichotomous phenomenon of motivated and amotivated people, proposes a model with six types of motives guiding human behavior: intrinsic, integrated, introjected, identified, external, and amotivated. People are intrinsically motivated if they protect forests because it is inherently interesting or enjoyable, whereas people who are amotivated lack an interest or see no reason to do so. In between, there are four different types of extrinsic motivations that vary in their degree of autonomy and internalization. Autonomy is understood as the psychological need for "the experience of choice" (Moller et al. 2006:104) and internalization, as "a proactive process through which people transform regulation by external contingencies into regulation by internal processes" (Deci et al. 1991:328). It is important to understand extrinsic motivation because most of the tasks individuals undertake are not inherently valued or enjoyable.

The least autonomous form of extrinsic motivation is external regulation in which an individual's behavior is motivated by an expected external reward or punishment and there is no internalization process involved. Introjected regulation is somewhat more autonomous given that feelings of guilt, anxiety, or pride, among others, drive behavior. In other words, introjection occurs when behavior is motivated by self-esteem contingencies and controlled by feelings of pressure to maintain or enhance self-esteem and the feeling of worth. A more autonomous form of extrinsic motivation is identified motivation, which occurs when an individual identifies with the personal importance of the behavior "and has thus accepted its regulation as his or her own" (Ryan and Deci 2000:62), but the drivers of action continue to be somewhat external to the self. The most autonomous form of extrinsic motivation is integrated motivation, in which identified motivations have been fully assimilated to the self. Integrated and intrinsic motivations are both autonomous forms of motivations; however, they differ in the sense that under integrated motivation the action is motivated by its instrumental value, whereas under intrinsic motivation the action is motivated by its inherent value. In this framework, there is no ideal sequence or "evolution" of motivations, or, in the authors' own words, "we do not suggest that the continuum underlying types of extrinsic motivation is a developmental continuum" (Ryan and Deci 2000:62).

Three types of feelings determine how people move through different types of motivations: autonomy, competence, and social relatedness. Any external reward that affects one of these three "moderators" is expected to affect intrinsic motivations. Interventions that support autonomy and feelings of self-efficacy, i.e., feeling capable or as having the skills to perform an activity, and that enhance or activate one's relationship to others as well as one's self-image (social relatedness) are expected to maintain intrinsic motivation for a task and more self-determined types of extrinsic motivation. For example, social interventions perceived as controlling have an effect on individuals' feelings of autonomy, thus negatively affecting intrinsic motivations to perform a task.

As described by Moros et al. (2017), empirical analyses in environmental psychology and environmental studies commonly rely on self-reported responses to questionnaire items to identify both the frequency of environmental practices and the patterns of attitudes, beliefs, and motivations that drive such reported behavior (Steg and Vlek 2009). Ruiz-Mallén et al. (2015) and Souto et al. (2014), for example, explored engagement in community-based conservation activities, while Greiner and colleagues (Greiner et al. 2009, Greiner 2015) analyzed farmers' willingness to participate in biodiversity contracts. These studies make use of semistructured interviews, surveys based on Likert scales, and focus groups to capture individuals' reasons to participate in conservation programs. However, this body of literature refers to attitudes, motivations, social norms, emotions, and perceptions as if they were equivalent, which limits its comparability, because no unified language is used.

Nonetheless, despite being measured and labeled in different ways, most of the studies in this field report two broad categories: instrumental versus noninstrumental reasons. Instrumental reasons include economic benefits derived from ecosystem services or social rewards such as recognition or reputation, whereas noninstrumental reasons include a sense of moral duty, respect for nature and animals, or stewardship ethics (Rode et al. 2015). In general, strong noninstrumental reasons favoring conservation positively correlate to proenvironmental behavior (Lynne et al. 1988, Beedell and Rehman 1999, Ryan et al. 2003, Price and Leviston 2014), whereas strong instrumental reasons toward profit maximization affect proenvironmental behavior either negatively or not at all (Ryan et al. 2003, Greiner et al. 2009)

In both environmental psychology and environmental studies, different types of motivations are reported to guide proenvironmental behavior. However, most of the studies applied to rural contexts focus on the effect of attitudes/motivations in environmental practices and conservation behavior (Gelcich et al. 2008, Greiner et al. 2009, Greiner 2015). To our knowledge, we are the first to link such psychological aspects to self-reported land-use change.

\section{METHODS}

\section{Site description}

The study was carried out in the region of El Caraño within the rural area of Florencia, an Amazonian city in southwestern Colombia. The study area is part of the Amazon foothills, a region that links the Andes with the Amazon basin, a key biodiversity ecotone and a major area of deforestation. Our study involves participants from 13 rural districts from El Caraño, a colonization frontier where displaced families from other regions in Colombia have moved over the last 40 years. These villages were included in the study because they are located in the headwaters of the Hacha River, the main water source for the 170,000 urban inhabitants of the city of Florencia, and because of the significant area of remaining forest they harbor (Moros et al. 2017). 
Table 1. Description of items and the correspondent statements of motivations survey. Source: Moros et al. (2017).

\begin{tabular}{ll}
\hline \hline Motivation Type & Survey Statements \\
\hline Intrinsic & 1. "I enjoy when I do not clear the forest." \\
& 2. "I see myself as someone who does not clear the forests." \\
Guilt or regret & 1. "I would feel guilty if I clear the forests." \\
2. "I would regret if I clear the forests." & 1. "I would be criticized by my neighbors if I clear the forests." \\
Social & 2. "Significant others would be upset if I clear the forests." \\
Extrinsic, payments & "I would take care of forests only if I am paid to do so." \\
Extrinsic, fines & "I do not cut down the forests because of fear [of] fines that might be imposed by environmental authorities." \\
Amotivation &
\end{tabular}

Agriculture and cattle ranching have driven forest clearing in El Caraño (Vásquez 2015), and the area is populated by more than 100 families, mainly smallholders who cultivate staple foods combined with coffee, sugarcane, and pastures. There are few large farms; average farm size in the area is $35 \mathrm{ha}$, and the median is 15 ha (Vélez et al. 2016).

In our fieldwork, farmers mentioned deforestation as their main environmental concern caused mainly by conversion to subsistence agriculture. There are no official records of deforestation rates for our study area, but, based on available forest cover data for the 13 rural districts that were part of the study zone, 7879 ha of the 10,588 ha $(74 \%)$ is still forested. Almost $19 \%$ of the forest in the zone is highly vulnerable to deforestation because of its proximity to roads and to the agricultural frontier. On average, forests cover $50 \%$ of the farms, whereas the rest is allocated to pastures; cash crops, such as coffee and sugarcane; and subsistence crops. The villages in the study area are located at higher altitudes and are adjacent to two national protected areas (Vélez et al. 2016).

Smallholders live in poverty: Incomes are low, access to education is limited, and they possess few or no assets. Average household size is 4 people, and migration patterns have been very dynamic: People arrived in the region 11 years ago, on average, but there is a large dispersion in the data, with some households having resided in the area for more than 40 years, and others having resided there for just a few months. Fewer than $40 \%$ of households declare that they have a legal land title (Vélez et al. 2016).

\section{Data and variables}

Our source of data is a household survey conducted by Vélez et al. (2016) between June and September 2016 in 13 villages. Although we tried to contact all households in the study area, we reached only 64 respondents, equivalent to approximately $60 \%$ of household heads in the villages, according to our own field assessment because there are no recent census data for the region. Dwellers are mainly mestizo peasants, from several regions in Colombia that have been forced to leave more productive rural areas and move to this agricultural frontier.

In the survey, we asked about motivations to protect forests, sociodemographics, productive practices, perceptions of environmental problems, existing forms of social capital, and land-use history (see Appendix 1 for full questionnaire in Spanish). The data helped us establish whether farmers have cleared forests since their arrival in the region and which socio-demographic and economic conditions might have influenced that behavior.
We designed a logit model in which we explain the decision of farmers to clear forest as a function of different social, economic, biophysical, and motivational factors, following those usually measured in the literature. The biophysical variables linked to deforestation are slope, altitude, and distance to markets. Farmers are expected to clear forest for agriculture if the land is suitable for cultivation in terms of slope and altitude, and if they are close to markets, which reduces transaction costs. The economic characteristics include self-reported measures of household income; farm size, as a proxy for wealth; and whether households engage in commercial cultivation, i.e., coffee, sugar, and cattle ranching. We expect wealthier households and those engaged in commercial activities to have engaged in forest clearing. As for the social characteristics of the household, we include the time of residence on the farm; household size; a binary variable relating to land tenure, i.e., property title; age of the household head; and a binary variable for participation in local, voluntary organizations. We ran a comparison of these variables between the samples to identify variables that could influence the decision to cut forest. For this, we used a two-sample Fligner-Policello robust rank-order test for ordinal or interval data and chi-square test for categorical data. The two-sample Fligner-Policello robust rank-order test is an alternative of the Wilcoxon-Mann-Whitney test that assumes neither normality, nor equal variances, nor equal distribution (Feltovich 2003).

Finally, we rely on the questionnaire developed by Moros et al. (2017) to measure motivations among rural dwellers to protect the forest. This questionnaire follows SDT and Pelletier et al.'s (1998) motivation toward the environment scale. The survey contains 9 statements intended to measure 5 different types of reasons to protect the forests: intrinsic, guilt/regret, social, extrinsic motivations, and lack of motivation (see Table 1 for a summary of survey statements). We would like to point out that the original motivation questionnaire was made up of 24 items. The 9 items we used to capture each type of motivation are those that after conducting a factor analysis, had a factor loading of above 0.55 as suggested by Hair et al. (2009). The survey, designed and implemented in Spanish by native speakers, used a 4-point bipolar Likert scale to capture variations in the motivations to protect forests. The scale is symmetric, ranging from 1 (totally disagree) to 4 (totally agree). Items were presented in the same order each time. Although we did not control for order effects, items were spread through the entire survey, thus reducing the risk of consistency across responses in relation to the motivations. For intrinsic, guilt/regret, and social motivations, we created 
indexes of responses giving equal weights to each item considering that, to our knowledge, there are no theoretical reasons to impute different weights to particular items.

Following SDT, we expect individuals with higher levels of intrinsic, guilt, and social motivations to be less likely to clear the forests because they have internalized the importance of taking care of the forests either because of pleasure, i.e., intrinsic motivations; self-approval, i.e., guilt- and regret-related motivations; or social approval, i.e., social motivations. Further, we expect intrinsic motivations to be stronger predictors of forest protection compared with less self-determined types of motivations (guilt, regret, social, or external) because, as mentioned previously, intrinsic motivations have been shown to increase proenvironmental behaviors (De Groot and Steg 2010). For extrinsic motivators, such as potential payments and fines, we expect a positive relationship with deforestation because, for these individuals, taking care of forest is contingent on external rewards or punishments, i.e., proenvironmental behavior is not internalized. In this line of reasoning, we expect amotivated individuals to be the most likely to deforest when compared with all other motivational types because this type of motivation is the least autonomous and self-determined.

\section{RESULTS}

\section{Descriptive results}

We used two nonparametric tests, the two-sample FlignerPolicello robust rank-order test for ordinal or interval data and the chi-square test for categorical data, to explore whether households that had cleared forests since their arrival at the farm (33\% of respondents) were significantly different from their counterparts (Table 2). We observed that the two samples are similar in most biophysical and productive characteristics, except that farms that report having cut down forests are larger, have more land in forests, and are farther away from main roads than farms that have not been deforested. Also, the percentages of sugarcane growers and cattle ranchers are significantly higher for those households that have cut down forests. The households that have deforested are significantly more dependent on crop-related income than their counterparts. Demographic characteristics such as education, household size, and age of the household head are not significantly different between the two samples. Only the time of residence is different, with households that have engaged in deforestation having resided in the region for longer. Regarding motivations, intrinsic and social motivations are, as expected, significantly lower among heads of households that report having cut down forests.

\section{Logistic model}

We built a logistic model to assess the role of different variables in predicting the binary decision of having cut down forest in the past (has cut down forest $=1$; has not cut down forest $=0$ ). We report odds ratios for 8 models in Table 3. Model (1) includes biophysical, socio-economic, and income source variables. Models (2) to (7) include a different type of motivation in each regression. We do not report a model including all types of motivations at the same time because, although they capture different types of motives, some of them are correlated causing multicollinearity. This correlation implies that each motivation coefficient in models (2) to (7) could be capturing other motives.
Table 4 reports a correlation matrix showing that, in fact, four correlations are statistically significant. Intrinsic and guilt-related motivations are, as expected by SDT theory, positively correlated. Payments for conservation, a specific type of extrinsic motivation, is negatively correlated with intrinsic and guilt motivations, i.e., the two types of most internalized and autonomous motivations. We found an unexpected significant correlation between fines and social motivations, which are positively correlated, meaning that people who reported fines to be an important motive for forest conservation also reported peer pressure from neighbors and relatives as an important driver for the task. We also calculated the variance inflation factor for these variables to analyze the severity of multicollinearity. We found that all motivation coefficients are inflated by an order of 4 or more, indicating the impossibility of combining all the variables in the same model. Thus, to have stable and reliable beta coefficients, we first test the different motivations independently in models (2) to (7) because it is in our interest to disentangle the differences between types of motivations and deforestation behavior. However, as a robustness test, in Table 5, we repeat the models in Table 3 with different combinations of motivations. In each version, models (8) to (13), we include those motivations that are not significantly correlated with each other, and results are consistent. We do not include a model with a motivation index, because our interest, beyond asserting the value of motivations in decision making, is to find out which of them are significantly associated with specific behaviors. By presenting an aggregate index, we would lose that information. SDT theory precisely argues the relevance of understanding motivation as a continuum and not as an aggregated dichotomous phenomenon. In fact, policy instruments may affect each motivation type differently (see Moros et al. 2017).

Variables commonly reported in the literature as drivers of deforestation, such as farm size, altitude, distance to nearest road, and plot slope, do not affect the likelihood of cutting down forests in our study, nor do socio-demographic variables, such as age, education, or household size, predict deforestation. Nonetheless, households that report having sugarcane on their farm are more likely to deforest across models. Likewise, households farther away from main roads are more likely to have cut down forests since their arrival to the plot. For our particular interest, those heads of households who report more intrinsic motivations to protect forests are less likely to deforest, whereas those that report payments as the only reason for forest protection are more likely to cut down forests. This result is robust to different specifications, even those that include different motivations simultaneously. Heads of households lacking any motivation to protect forests are also more likely to deforest. However, the amotivated variable loses significance when we include other types of motivations in the same model. None of the other motivations, i.e., guilt, social, or fines, significantly explain having cut down forest areas in any of the models reported.

\section{DISCUSSION}

We move beyond the proximate and distal causes of land-use change and consider the effect of individual motivations on deforestation in the region with the highest deforestation rates in Colombia. Controlling for socio-economic factors, we find that intrinsic motivations negatively correlate with self-reported deforestation. In addition, amotivated and extrinsically 
Table 2. Descriptive characteristics of farmers. Note: Asterisks represent differences between groups, using two-sample Fligner-Policello robust rank-order test for ordinal or interval data and chi-square test for categorical data. $* * * P<0.01, * * P<0.05, * P<0.1$. Standard errors in parentheses.

\begin{tabular}{|c|c|c|c|}
\hline & $\begin{array}{l}\text { Households that Have Cut } \\
\text { Forests } \\
\mathrm{N}=21\end{array}$ & $\begin{array}{l}\text { Households that Have } \\
\text { Not Cut Forests } \\
\mathrm{N}=43\end{array}$ & $P$ value \\
\hline \multicolumn{4}{|l|}{ Biophysical and productive characteristics of the farm } \\
\hline Size of the farm (hectares) & $30.14 * *(25.82)$ & $25.55(42.21)$ & 0.0334 \\
\hline Size of the productive area (hectares) ${ }^{\dagger}$ & $8.91(6.70)$ & $9.73(18.65)$ & 0.1562 \\
\hline Proportion of productive area relative to total area (\%) & $29.90(18.09)$ & $32.47(23.44)$ & 0.4093 \\
\hline Size of area in forest (hectares) & $13.26^{* *}(17.69)$ & $10.66(19.08)$ & 0.0375 \\
\hline Proportion of area in forests relative to total area (\%) & $39.66 *(22.12)$ & $31.66(23.36)$ & 0.0756 \\
\hline Proportion of area in forests/stubble relative to total area (\%) & $54.41(17.48)$ & $59.32(23.40)$ & 0.1570 \\
\hline Altitude (meters above sea level) & $1065.05(149.71)$ & $999.62(210.83)$ & 0.1263 \\
\hline Slope (degrees) & $44.469(8.399)$ & $41.562(12.361)$ & 0.1346 \\
\hline Distance to nearest road (meters) & $2167.82 * * *(1910.30)$ & $806.40(1258.94)$ & 0.0096 \\
\hline \multicolumn{4}{|l|}{ Productive uses of the land } \\
\hline Coffee $(\%$ farmers $)$ & $71.42(46.29)$ & $65.11(48.22)$ & 0.614 \\
\hline Coffee (hectares) & $1.40(0.973)$ & $1.12(0.7441)$ & 0.219 \\
\hline Sugarcane ( $\%$ farmers $)$ & $80.95 * *(40.24)$ & $51.16(50.58)$ & 0.022 \\
\hline Sugarcane (hectares) & $95.25(1.078)$ & $80.74(0.969)$ & 0.484 \\
\hline Pasture ( $\%$ farmers) & $85.71(35.86)$ & $67.44(47.41)$ & 0.120 \\
\hline Pasture (hectares) & $10.19(13.65)$ & $7.39(11.73)$ & 0.128 \\
\hline Cattle (\% farmers) & $61.90 * *(49.76)$ & $34.88(48.22)$ & 0.041 \\
\hline Cattle (units) & $8.38(8.99)$ & $9.86(12.93)$ & 0.372 \\
\hline \multicolumn{4}{|l|}{ Socioeconomic characteristics of the household } \\
\hline Time living on the farm (years) & $15.76 * *(14.78)$ & $10.93(13.01)$ & 0.0371 \\
\hline Household size & $3.67(1.65)$ & $3.72(1.67)$ & 0.4778 \\
\hline Formal property of land $(\%)$ & $38.09(49.76)$ & $44.18(50.25)$ & 0.643 \\
\hline Education level of most educated member of household (years) & $6.67(3.71)$ & $6.66(3.84)$ & 0.4622 \\
\hline Education level of the household head (years) & $4.09(3.88)$ & $3.61(3.25)$ & 0.4454 \\
\hline Age of the household head (years) & $50.05(15.03)$ & $50.70(13.58)$ & 0.4506 \\
\hline Sex of the household head ( $\%$ male $)$ & $80.95(40.23)$ & $81.4(39.37)$ & 0.966 \\
\hline Monthly income (US\$) & $142.95(120.53)$ & $178.15(143.66)$ & 0.1842 \\
\hline Preference for their offspring to become farmers $(\%)$ & $65.00(48.94)$ & $68.29(47.11)$ & 0.8357 \\
\hline \multicolumn{4}{|l|}{ Social capital and social networks } \\
\hline Household head member of productive or community organization $(\%)$ & $19.04(40.24)$ & $16.27(37.35)$ & 0.783 \\
\hline People in this rural district (1-3 scale): & $2.14(0.654)$ & $2.23(0.751)$ & 0.2993 \\
\hline Help each other a lot $(\%)$ & 28.57 & 41.86 & \\
\hline Do not help each other that much (\%) & 57.14 & 39.53 & \\
\hline Do not help each other at all (\%) & 14.29 & 18.6 & \\
\hline \multicolumn{4}{|l|}{ Income sources ( $\%$ farmers) } \\
\hline Crops & $80.95(40.24)$ & $65.11(48.22)$ & 0.193 \\
\hline Cattle ranching & $33.33(48.30)$ & $18.60(39.37)$ & 0.192 \\
\hline Wage laborer & $57.14(50.71)$ & $53.48(50.47)$ & 0.783 \\
\hline Self-employed & $0(0)$ & $6.98(25.78)$ & 0.215 \\
\hline Employee & $9.5(30.08)$ & $13.95(35.06)$ & 0.615 \\
\hline Diversified income source & $95.24(21.82)$ & $72.09(45.38)$ & 0.1351 \\
\hline \multicolumn{4}{|l|}{ Main income source ( $\%$ farmers) } \\
\hline Crops & $57.14 *(50.71)$ & $32.55(47.41)$ & 0.060 \\
\hline Cattle ranching & $14.28(35.86)$ & $4.65(21.31)$ & 0.177 \\
\hline Wage laborer & $9.52(30.08)$ & $25.58(44.15)$ & 0.134 \\
\hline Self-employed & $0(0)$ & $4.65(21.31)$ & 0.315 \\
\hline Employee & $4.76(21.83)$ & $9.30(29.39)$ & 0.525 \\
\hline \multicolumn{4}{|l|}{ Motivations (scale 1-4) } \\
\hline Intrinsic & $2.85^{* *}(0.76)$ & $3.22(0.69)$ & 0.0306 \\
\hline "I see myself as someone who does not clear the forests." & $2.66^{*}(1.02)$ & $3.09(0.95)$ & 0.0639 \\
\hline "I enjoy when I do not clear the forest." & $3.04 *(0.74)$ & $3.34(0.78)$ & 0.0644 \\
\hline Guilt or regret & $3.09(0.77)$ & $3.24(0.69)$ & 0.2527 \\
\hline "I would feel guilty if I clear the forests." & $3.09(0.89)$ & $3.37(0.69)$ & 0.1653 \\
\hline "I would regret if I clear the forests." & $3.09(0.94)$ & $3.11(0.90)$ & 0.4760 \\
\hline Social & $2.26^{*}(0.83)$ & $2.62(0.92)$ & 0.0673 \\
\hline "I would be criticized by my neighbors if I clear the forests." & $2.19(1.17)$ & $2.25(1.16)$ & 0.4178 \\
\hline "Significant others would be upset if I clear the forests." & $2.33 * *(1.06)$ & $3(1.09)$ & 0.0108 \\
\hline \multicolumn{4}{|l|}{ External, payments } \\
\hline "I would take care of the forests only if I am paid to do so." & $3.43(1.07)$ & $3.11(1.16)$ & 0.1622 \\
\hline \multicolumn{4}{|l|}{ External, fines } \\
\hline "I do not cut down the forest because of fear [of] fines." & $1.95(1.07)$ & $2.23(1.21)$ & 0.2396 \\
\hline \multicolumn{4}{|l|}{ A-motivation } \\
\hline "I do not see what I can get by protecting the forests." & $2(1.18)$ & $1.744(1.05)$ & 0.2341 \\
\hline
\end{tabular}

Note that only $25.6 \%$ individuals that reported to have not cut forest and $47.6 \%$ that reported to have cut forest knew and reported the size of the productive area.

Kolmogorov-Smirnov test of equality of distributions has a $\mathrm{P}$ value of 0.415 , so there are not significant differences in the distributions of income between the two groups. 
Table 3. Logistic model for binary variable of having cut down forests in the past controlling for biophysical, socio-demographic, and motivation variables. ${ }^{* * *} P<0.01,{ }^{* *} P<0.05,{ }^{*} P<0.1$. Standard errors in parentheses.

\begin{tabular}{|c|c|c|c|c|c|c|c|}
\hline$\underline{\text { Variables }}$ & $(1)$ & (2) & (3) & (4) & $(5)$ & $(6)$ & $(7)$ \\
\hline Size of the farm & $\begin{array}{l}0.00936 \\
(0.0205)\end{array}$ & $\begin{array}{c}0.0648 \\
(0.0496)\end{array}$ & $\begin{array}{l}0.00768 \\
(0.0208)\end{array}$ & $\begin{array}{l}0.00824 \\
(0.0207)\end{array}$ & $\begin{array}{c}0.0119 \\
(0.0223)\end{array}$ & $\begin{array}{l}0.00740 \\
(0.0208)\end{array}$ & $\begin{array}{l}0.00225 \\
(0.0214)\end{array}$ \\
\hline Altitude & $\begin{array}{l}-0.00174 \\
(0.00306)\end{array}$ & $\begin{array}{c}0.00216 \\
(0.00455)\end{array}$ & $\begin{array}{l}-0.00188 \\
(0.00320)\end{array}$ & $\begin{array}{l}-0.00201 \\
(0.00309)\end{array}$ & $\begin{array}{l}-0.000534 \\
(0.00383)\end{array}$ & $\begin{array}{l}-0.00214 \\
(0.00315)\end{array}$ & $\begin{array}{l}-0.00132 \\
(0.00395)\end{array}$ \\
\hline $\begin{array}{l}\text { Distance to nearest } \\
\text { road }\end{array}$ & $\begin{array}{c}0.000575 \\
(0.000402)\end{array}$ & $\begin{array}{l}0.00226^{*} \\
(0.00122)\end{array}$ & $\begin{array}{c}0.000535 \\
(0.000408)\end{array}$ & $\begin{array}{c}0.000618 \\
(0.000421)\end{array}$ & $\begin{array}{c}0.000404 \\
(0.000432)\end{array}$ & $\begin{array}{c}0.000644 \\
(0.000432)\end{array}$ & $\begin{array}{l}0.000893^{*} \\
(0.000492)\end{array}$ \\
\hline Slope & $\begin{array}{c}0.0433 \\
(0.0511)\end{array}$ & $\begin{array}{l}0.267^{*} \\
(0.145)\end{array}$ & $\begin{array}{c}0.0507 \\
(0.0533)\end{array}$ & $\begin{array}{c}0.0491 \\
(0.0542)\end{array}$ & $\begin{array}{c}0.0603 \\
(0.0556)\end{array}$ & $\begin{array}{c}0.0537 \\
(0.0567)\end{array}$ & $\begin{array}{c}0.0250 \\
(0.0607)\end{array}$ \\
\hline Coffee & $\begin{array}{l}-0.548 \\
(1.069)\end{array}$ & $\begin{array}{l}-4.188^{*} \\
(2.312)\end{array}$ & $\begin{array}{l}-0.392 \\
(1.101)\end{array}$ & $\begin{array}{l}-0.562 \\
(1.058)\end{array}$ & $\begin{array}{l}-1.175 \\
(1.180)\end{array}$ & $\begin{array}{l}-0.720 \\
(1.112)\end{array}$ & $\begin{array}{l}-1.096 \\
(1.263)\end{array}$ \\
\hline Sugarcane & $\begin{array}{l}2.062^{*} \\
(1.114)\end{array}$ & $\begin{array}{l}7.476^{* *} \\
(3.371)\end{array}$ & $\begin{array}{l}2.119^{*} \\
(1.111)\end{array}$ & $\begin{array}{l}2.051^{*} \\
(1.123)\end{array}$ & $\begin{array}{l}2.048^{*} \\
(1.146)\end{array}$ & $\begin{array}{l}1.959^{*} \\
(1.131)\end{array}$ & $\begin{array}{l}2.396^{* *} \\
(1.190)\end{array}$ \\
\hline Cattle ranching & $\begin{array}{l}1.570 \\
(1.286)\end{array}$ & $\begin{array}{l}7.282 * \\
(3.912)\end{array}$ & $\begin{array}{l}1.645 \\
(1.301)\end{array}$ & $\begin{array}{l}1.560 \\
(1.280)\end{array}$ & $\begin{array}{l}2.443 \\
(1.556)\end{array}$ & $\begin{array}{l}1.684 \\
(1.316)\end{array}$ & $\begin{array}{l}1.934 \\
(1.418)\end{array}$ \\
\hline $\begin{array}{l}\text { Time living on the } \\
\text { farm }\end{array}$ & $\begin{array}{l}0.0165 \\
(0.0384)\end{array}$ & $\begin{array}{c}-0.123 \\
(0.0859)\end{array}$ & $\begin{array}{c}0.0183 \\
(0.0383)\end{array}$ & $\begin{array}{c}0.0153 \\
(0.0386)\end{array}$ & $\begin{array}{c}0.0185 \\
(0.0409)\end{array}$ & $\begin{array}{c}0.0184 \\
(0.0387)\end{array}$ & $\begin{array}{c}0.0419 \\
(0.0442)\end{array}$ \\
\hline Household size & $\begin{array}{l}-0.177 \\
(0.276)\end{array}$ & $\begin{array}{l}0.0158 \\
(0.668)\end{array}$ & $\begin{array}{l}-0.133 \\
(0.289)\end{array}$ & $\begin{array}{l}-0.159 \\
(0.276)\end{array}$ & $\begin{array}{l}-0.141 \\
(0.322)\end{array}$ & $\begin{array}{l}-0.146 \\
(0.276)\end{array}$ & $\begin{array}{l}-0.143 \\
(0.308)\end{array}$ \\
\hline $\begin{array}{l}\text { Formal property } \\
\text { of land }\end{array}$ & $\begin{array}{l}-1.205 \\
(1.196)\end{array}$ & $\begin{array}{l}-1.471 \\
(2.000)\end{array}$ & $\begin{array}{l}-1.248 \\
(1.186)\end{array}$ & $\begin{array}{l}-1.094 \\
(1.215)\end{array}$ & $\begin{array}{l}-1.609 \\
(1.317)\end{array}$ & $\begin{array}{l}-1.219 \\
(1.203)\end{array}$ & $\begin{array}{l}-1.563 \\
(1.375)\end{array}$ \\
\hline $\begin{array}{l}\text { Crops main } \\
\text { income source }\end{array}$ & $\begin{array}{c}0.660 \\
(1.026)\end{array}$ & $\begin{array}{l}-4.144 \\
(2.927)\end{array}$ & $\begin{array}{c}0.488 \\
(1.099)\end{array}$ & $\begin{array}{c}0.662 \\
(1.028)\end{array}$ & $\begin{array}{c}0.883 \\
(1.154)\end{array}$ & $\begin{array}{c}0.615 \\
(1.034)\end{array}$ & $\begin{array}{c}0.574 \\
(1.218)\end{array}$ \\
\hline $\begin{array}{l}\text { Income } \\
\text { US\$ }\end{array}$ & $\begin{array}{l}-0.00190 \\
(0.00772)\end{array}$ & $\begin{array}{l}-0.0238 \\
(0.0176)\end{array}$ & $\begin{array}{l}-0.00166 \\
(0.00753)\end{array}$ & $\begin{array}{l}-0.00120 \\
(0.00778)\end{array}$ & $\begin{array}{l}-0.00574 \\
(0.00804)\end{array}$ & $\begin{array}{l}-0.00131 \\
(0.00792)\end{array}$ & $\begin{array}{l}-0.00375 \\
(0.00782)\end{array}$ \\
\hline $\begin{array}{l}\text { Member of } \\
\text { productive or } \\
\text { community } \\
\text { organization }\end{array}$ & $\begin{array}{l}-0.555 \\
(1.413)\end{array}$ & $\begin{array}{l}6.466^{*} \\
(3.684)\end{array}$ & $\begin{array}{l}-0.384 \\
(1.468)\end{array}$ & $\begin{array}{l}-0.815 \\
(1.540)\end{array}$ & $\begin{array}{c}0.163 \\
(1.531)\end{array}$ & $\begin{array}{l}-0.728 \\
(1.463)\end{array}$ & $\begin{array}{l}-0.597 \\
(1.546)\end{array}$ \\
\hline $\begin{array}{l}\text { Intrinsic } \\
\text { motivations }\end{array}$ & & $\begin{array}{c}-6.354^{* *} \\
(2.528)\end{array}$ & & & & & \\
\hline Guilt & & & $\begin{array}{l}-0.352 \\
(0.684)\end{array}$ & & & & \\
\hline Social motivations & & & & $\begin{array}{l}-0.235 \\
(0.487)\end{array}$ & & & \\
\hline $\begin{array}{l}\text { External } \\
\text { motivation, } \\
\text { payments }\end{array}$ & & & & & $\begin{array}{l}1.172^{*} \\
(0.604)\end{array}$ & & \\
\hline $\begin{array}{l}\text { External } \\
\text { motivation, fines }\end{array}$ & & & & & & $\begin{array}{l}-0.248 \\
(0.407)\end{array}$ & \\
\hline Amotivated & & & & & & & $\begin{array}{l}1.262^{* *} \\
(0.610)\end{array}$ \\
\hline Constant & $\begin{array}{l}-3.141 \\
(3.130)\end{array}$ & $\begin{array}{l}-1.427 \\
(7.370)\end{array}$ & $\begin{array}{l}-2.403 \\
(3.476)\end{array}$ & $\begin{array}{l}-2.674 \\
(3.253)\end{array}$ & $\begin{array}{l}-8.890^{*} \\
(5.147)\end{array}$ & $\begin{array}{l}-2.785 \\
(3.188)\end{array}$ & $\begin{array}{l}-5.331 \\
(3.937)\end{array}$ \\
\hline Observations & 50 & 50 & 50 & 50 & 50 & 50 & 50 \\
\hline
\end{tabular}

Table 4. Correlation matrix of motivation variables. $P$ values in parentheses.

\begin{tabular}{|c|c|c|c|c|c|}
\hline & Intrinsic & Guilt & Social & Payments & Fines \\
\hline Guilt & $\begin{array}{c}0.4472 \\
(0.0002)\end{array}$ & & & & \\
\hline Social & $\begin{array}{l}-0.0555 \\
(0.6634)\end{array}$ & $\begin{array}{c}0.0590 \\
(0.6431)\end{array}$ & & & \\
\hline Payments & $\begin{array}{l}-0.4396 \\
(0.0003)\end{array}$ & $\begin{array}{l}-0.2881 \\
(0.0210)\end{array}$ & $\begin{array}{c}0.1536 \\
(0.2257)\end{array}$ & & \\
\hline Fines & $\begin{array}{c}0.0202 \\
(0.8739)\end{array}$ & $\begin{array}{c}0.0521 \\
(0.6826)\end{array}$ & $\begin{array}{c}0.5194 \\
(0.0000)\end{array}$ & $\begin{array}{c}0.1084 \\
(0.3938)\end{array}$ & \\
\hline Amotivated & $\begin{array}{l}-0.0972 \\
(0.4448)\end{array}$ & $\begin{array}{l}-0.0883 \\
(0.4876)\end{array}$ & $\begin{array}{c}0.0256 \\
(0.8411)\end{array}$ & $\begin{array}{c}0.1591 \\
(0.2092)\end{array}$ & $\begin{array}{c}0.0567 \\
(0.6565)\end{array}$ \\
\hline
\end{tabular}


Table 5. Logistic model for binary variable of having cut down forests in the past controlling for biophysical, socio-demographic, and motivation variables. ${ }^{* * *} P<0.01,{ }^{* *} P<0.05,{ }^{*} P<0.1$. Standard errors in parentheses.

\begin{tabular}{|c|c|c|c|c|c|c|}
\hline Variables & $(8)$ & (9) & $(10)$ & $(11)$ & (12) & (13) \\
\hline \multicolumn{7}{|l|}{ Size of the farm } \\
\hline & $\begin{array}{c}0.0549 \\
(0.0579)\end{array}$ & $\begin{array}{c}0.0512 \\
(0.0643)\end{array}$ & $\begin{array}{l}0.00460 \\
(0.0221)\end{array}$ & $\begin{array}{l}0.00382 \\
(0.0219)\end{array}$ & $\begin{array}{l}0.00740 \\
(0.0264)\end{array}$ & $\begin{array}{c}0.000555 \\
(0.0257)\end{array}$ \\
\hline Altitude & $\begin{array}{c}0.00221 \\
(0.00538)\end{array}$ & $\begin{array}{c}0.00181 \\
(0.00477)\end{array}$ & $\begin{array}{l}-0.00141 \\
(0.00384)\end{array}$ & $\begin{array}{l}-0.00161 \\
(0.00393)\end{array}$ & $\begin{array}{c}5.33 \mathrm{e}-05 \\
(0.00446)\end{array}$ & $\begin{array}{c}-0.000418 \\
(0.00460)\end{array}$ \\
\hline Distance to nearest road & $\begin{array}{l}0.00277^{*} \\
(0.00158)\end{array}$ & $\begin{array}{l}0.00296^{*} \\
(0.00160)\end{array}$ & $\begin{array}{c}0.00110^{*} \\
(0.000613)\end{array}$ & $\begin{array}{c}0.00121^{*} \\
(0.000640)\end{array}$ & $\begin{array}{c}0.000683 \\
(0.000538)\end{array}$ & $\begin{array}{c}0.000887 \\
(0.000582)\end{array}$ \\
\hline Slope & $\begin{array}{c}0.252 \\
(0.158)\end{array}$ & $\begin{array}{l}0.252^{*} \\
(0.151)\end{array}$ & $\begin{array}{c}0.0215 \\
(0.0709)\end{array}$ & $\begin{array}{c}0.0299 \\
(0.0791)\end{array}$ & $\begin{array}{c}0.0700 \\
(0.0737)\end{array}$ & $\begin{array}{c}0.101 \\
(0.0890)\end{array}$ \\
\hline Coffee & $\begin{array}{l}-4.882^{*} \\
(2.910)\end{array}$ & $\begin{array}{l}-5.372^{*} \\
(3.169)\end{array}$ & $\begin{array}{l}-1.633 \\
(1.494)\end{array}$ & $\begin{array}{c}-2.104 \\
(1.668)\end{array}$ & $\begin{array}{l}-1.734 \\
(1.338)\end{array}$ & $\begin{array}{l}-2.469 \\
(1.577)\end{array}$ \\
\hline Sugarcane & $\begin{array}{l}8.116^{* *} \\
(3.823)\end{array}$ & $\begin{array}{c}8.151^{* *} \\
(3.847)\end{array}$ & $\begin{array}{l}2.265^{*} \\
(1.232)\end{array}$ & $\begin{array}{l}2.066^{*} \\
(1.246)\end{array}$ & $\begin{array}{l}2.634^{*} \\
(1.368)\end{array}$ & $\begin{array}{l}2.460^{*} \\
(1.303)\end{array}$ \\
\hline Cattle ranching & $\begin{array}{l}7.460^{*} \\
(4.172)\end{array}$ & $\begin{array}{l}7.616^{*} \\
(4.013)\end{array}$ & $\begin{array}{c}1.722 \\
(1.425)\end{array}$ & $\begin{array}{c}2.193 \\
(1.585)\end{array}$ & $\begin{array}{c}2.682 \\
(1.654)\end{array}$ & $\begin{array}{l}3.844^{*} \\
(2.208)\end{array}$ \\
\hline Time living on the farm & $\begin{array}{c}-0.112 \\
(0.0922)\end{array}$ & $\begin{array}{c}-0.0906 \\
(0.0965)\end{array}$ & $\begin{array}{c}0.0382 \\
(0.0473)\end{array}$ & $\begin{array}{c}0.0520 \\
(0.0503)\end{array}$ & $\begin{array}{c}0.0248 \\
(0.0477)\end{array}$ & $\begin{array}{c}0.0491 \\
(0.0495)\end{array}$ \\
\hline Household size & $\begin{array}{l}-0.138 \\
(0.758)\end{array}$ & $\begin{array}{l}-0.256 \\
(0.730)\end{array}$ & $\begin{array}{l}-0.160 \\
(0.323)\end{array}$ & $\begin{array}{l}-0.169 \\
(0.319)\end{array}$ & $\begin{array}{c}-0.0690 \\
(0.341)\end{array}$ & $\begin{array}{l}-0.161 \\
(0.357)\end{array}$ \\
\hline Formal property of land & $\begin{array}{l}-1.584 \\
(2.237)\end{array}$ & $\begin{array}{l}-2.022 \\
(2.268)\end{array}$ & $\begin{array}{l}-1.221 \\
(1.545)\end{array}$ & $\begin{array}{l}-1.615 \\
(1.564)\end{array}$ & $\begin{array}{l}-1.503 \\
(1.441)\end{array}$ & $\begin{array}{l}-2.533 \\
(1.663)\end{array}$ \\
\hline Crops main income source & $\begin{array}{l}-4.113 \\
(3.098)\end{array}$ & $\begin{array}{l}-3.924 \\
(3.033)\end{array}$ & $\begin{array}{c}0.865 \\
(1.317)\end{array}$ & $\begin{array}{c}0.845 \\
(1.350)\end{array}$ & $\begin{array}{c}0.833 \\
(1.312)\end{array}$ & $\begin{array}{c}0.640 \\
(1.359)\end{array}$ \\
\hline Income & -0.0252 & -0.0248 & -0.00466 & -0.00506 & -0.00628 & -0.00578 \\
\hline US\$ & $(0.0197)$ & $(0.0197)$ & $(0.00823)$ & $(0.00859)$ & $(0.00788)$ & $(0.00848)$ \\
\hline $\begin{array}{l}\text { Member of productive or } \\
\text { community organization }\end{array}$ & $\begin{array}{c}6.338 \\
(4.142)\end{array}$ & $\begin{array}{c}5.886 \\
(4.059)\end{array}$ & $\begin{array}{l}-1.254 \\
(1.742)\end{array}$ & $\begin{array}{l}-1.311 \\
(1.682)\end{array}$ & $\begin{array}{l}-0.558 \\
(1.797)\end{array}$ & $\begin{array}{l}-0.500 \\
(1.780)\end{array}$ \\
\hline Intrinsic motivations & $\begin{array}{c}-6.430^{* *} \\
(2.825)\end{array}$ & $\begin{array}{c}-6.479 * * \\
(2.859)\end{array}$ & & & & \\
\hline Guilt & & & $\begin{array}{c}0.645 \\
(0.932)\end{array}$ & $\begin{array}{c}0.704 \\
(0.897)\end{array}$ & & \\
\hline Social motivations & $\begin{array}{l}-0.0861 \\
(0.847)\end{array}$ & & $\begin{array}{l}-0.432 \\
(0.572)\end{array}$ & & $\begin{array}{l}-0.860 \\
(0.702)\end{array}$ & \\
\hline External motivation, payments & & & & & $\begin{array}{l}1.282^{*} \\
(0.760)\end{array}$ & $\begin{array}{l}1.394^{*} \\
(0.792)\end{array}$ \\
\hline $\begin{array}{l}\text { External motivation, } \\
\text { fines }\end{array}$ & & $\begin{array}{l}-0.438 \\
(0.843)\end{array}$ & & $\begin{array}{l}-0.542 \\
(0.505)\end{array}$ & & $\begin{array}{c}-0.943 \\
(0.646)\end{array}$ \\
\hline Amotivated & $\begin{array}{c}1.096 \\
(1.096)\end{array}$ & $\begin{array}{l}1.442 \\
(1.413)\end{array}$ & $\begin{array}{l}1.474 * * \\
(0.712)\end{array}$ & $\begin{array}{c}1.647^{* *} \\
(0.788)\end{array}$ & $\begin{array}{c}0.730 \\
(0.645)\end{array}$ & $\begin{array}{l}1.031 \\
(0.733)\end{array}$ \\
\hline Constant & $\begin{array}{l}-1.937 \\
(8.822)\end{array}$ & $\begin{array}{l}-0.785 \\
(8.467)\end{array}$ & $\begin{array}{l}-6.201 \\
(4.555)\end{array}$ & $\begin{array}{l}-6.739 \\
(4.702)\end{array}$ & $\begin{array}{l}-10.04^{*} \\
(6.101)\end{array}$ & $\begin{array}{l}-11.90^{*} \\
(6.780)\end{array}$ \\
\hline Observations & 50 & 50 & 50 & 50 & 50 & 50 \\
\hline
\end{tabular}

motivated individuals report more deforestation. These results are novel and contribute to understanding the drivers of deforestation.

Our results are important because motivational factors can explain differences in self-reported deforestation even when households do not have significant differences in their socioeconomic characteristics or the biophysical conditions of their farms. Intrinsic motivations prevent deforestation, even in the context of an active deforestation frontier. Social motivations and guilt did not explain self-reported deforestation. This could be related to the lack of social cohesion among community members in this ongoing deforestation frontier with low levels of associativity, very loose or nonexistent kinship ties, and little social capital. Also, external motivations driven by expected fines for cutting the forest did not explain deforestation, a result consistent with the lack of enforcement and legitimacy of local environmental authorities in the study region.

One should be cautious about claiming causality with our empirical strategy and results. Our data report farmers' motivations at a certain point in time. Three months later, they are asked to report the history of forest clearing at a time when deforestation is a fait accompli. It could be argued that farmers are just creating a consistent narrative of forest use or that clearing practices determine motivations. In addition, we have no observed behavior, i.e., actual changes in forest cover, and rely exclusively on self-reported practices. Thus, at this point, we can only claim association between our dependent and independent variables. In addition, we acknowledge the small size of our sample and the possibility of some variables becoming significant once we increase it. 
Nevertheless, motivations are significant, and our results open an important and unexplored research agenda, and they raise important considerations for the implementation of conservation policies aiming at behavioral changes such as payment for ecosystems services. In particular, our results highlight the importance of considering the impacts on motivations when designing, implementing, and evaluating the effects of such types of policies to avoid possible crowding-out effects (Agrawal et al. 2015). Further research should move beyond self-reported behavior to actual behavior to establish a causal relationship between motivation and deforestation.

The literature on environmental psychology has explored the importance of motivations in determining urban proenvironmental behavior, whereas the experimental economics literature has explored the effect of economic incentives on individual motivation and forest conservation behavior with mixed results (Narloch et al. 2012, Moros et al. 2017, Salk et al. 2017). Thus, empirical studies exploring the effect of different types of motivations as drivers of deforestation are crucial for the design of tailored policies that consider fundamental drivers of individual behavior. Ignoring the role of motivations could affect the expected impact of conservation policies and the durability and stability of behavior over time.

Understanding the role of proenvironmental motivations as drivers of land-use change is the first step in a new research agenda aimed at designing policies that attempt to change mental models, via education and communication campaigns, along with structural changes aimed at improving farmers' poor social conditions. Motivations can play a crucial role in the success of interventions, especially in areas with low state presence and limited capacity to enforce traditional command and control interventions. New policies should aim to work on motivations, because they are an important piece of the behavioral change puzzle.

Responses to this article can be read online at: http://www.ecologyandsociety.org/issues/responses. php/10617

\section{Acknowledgments:}

This research has been possible thanks to the support of the U.S. Agency for International Development (USAID), under the program "Conservación y Gobernanza en el Piedemonte Amazónico," implemented by Fondo Patrimonio Natural. Its content is the responsibility of the authors and does not necessarily reflect the opinions of Patrimonio Natural, USAID, or the U.S. government. We thank Juan Sebastián Rodríguez for his excellent research assistance during this project.

\section{LITERATURE CITED}

Agrawal, A., A. Chhatre, and E. R. Gerber. 2015. Motivational crowding in sustainable development interventions. American Political Science Review 109(3):470-487. http://dx.doi.org/10.1017/ $\underline{\text { S0003055415000209 }}$
Ajzen, I. 1991. The theory of planned behavior. Organizational Behavior and Human Decision Processes 50(2):179-211. http://dx. doi.org/10.1016/0749-5978(91)90020-T

Beedell, J. D. C., and T. Rehman. 1999. Explaining farmers' conservation behaviour: why do farmers behave the way they do? Journal of Environmental Management 57:165-176. http://dx.doi. org/10.1006/jema.1999.0296

Byerlee, D., J. Stevenson, and N. Villoria. 2014. Does intensification slow crop land expansion or encourage deforestation? Global Food Security 3(2):92-98. http://dx.doi. org/10.1016/j.gfs.2014.04.001

Carrasco, L. R., C. Larrosa, E. J. Milner-Gulland, and D. P. Edwards. 2014. A double-edged sword for tropical forests. Science 346(6205):38-40. http://dx.doi.org/10.1126/science.1256685

Deci, E. L., R. J. Vallerand, L. G. Pelletier, and R. M. Ryan. 1991. Motivation and education: the self-determination perspective. Educational Psychologist 26(3-4):325-346. https://doi. org/10.1080/00461520.1991.9653137

DeFries, R. S., T. Rudel, M. Uriarte, and M. Hansen. 2010. Deforestation driven by urban population growth and agricultural trade in the twenty-first century. Nature Geoscience 3(3):178-181. http://dx.doi.org/10.1038/ngeo756

De Groot, J. I. M., and L. Steg. 2010. Relationships between value orientations, self-determined motivational types and proenvironmental behavioural intentions. Journal of Environmental Psychology 30(4):368-378. http://dx.doi.org/10.1016/j.jenvp.2010.04.002

Feltovich, N. 2003. Nonparametric tests of differences in medians: comparison of the Wilcoxon-Mann-Whitney and robust rank-order tests. Experimental Economics 6(3):273-297. http://dx.doi.org/10.1023/A:1026273319211

Festré, A., and P. Garrouste. 2015. Theory and evidence in psychology and economics about motivation crowding out: a possible convergence? Journal of Economic Surveys 29(2):339356. https://doi.org/10.1111/joes. 12059

Fishbein, M., and I. Ajzen. 1975. Belief, attitude, intention, and behavior: an introduction to theory and research. Addison-Wesley, Reading, Massachusetts, USA.

Food and Agriculture Organization of the United Nations (FAO). 2015. Global forest resources assessment 2015: desk reference. FAO, Rome, Italy.

Geist, H. J., and E. F. Lambin. 2001. What drives tropical deforestation. Land Use and Cover Change (LUCC) Report Series No. 4. LUCC International Project Office, University of Louvain, Louvain-la-Neuve, Belgium.

Geist, H. J., and E. F. Lambin. 2002. Proximate causes and underlying driving forces of tropical deforestation: tropical forests are disappearing as the result of many pressures, both local and regional, acting in various combinations in different geographical locations. BioScience 52(2):143-150. http://dx.doi.org/10.1641/0006-3568 (2002)052[0143:PCAUDF]2.0.CO;2

Gelcich, S., M. J. Kaiser, J. C. Castilla, and G. Edwards-Jones. 2008. Engagement in co-management of marine benthic 
resources influences environmental perceptions of artisanal fishers. Environmental Conservation 35(1):36-45. http://dx.doi. org/10.1017/S0376892908004475

Greiner, R. 2015. Motivations and attitudes influence farmers' willingness to participate in biodiversity conservation contracts. Agricultural Systems 137:154-165. http://dx.doi.org/10.1016/j. agsy.2015.04.005

Greiner, R., L. Patterson, and O. Miller. 2009. Motivations, risk perceptions and adoption of conservation practices by farmers. Agricultural Systems 99(2-3):86-104. http://dx.doi.org/10.1016/j. agsy.2008.10.003

Hair, J. F., Jr., W. C. Black, B. J. Babin, and R. E. Anderson. 2009. Multivariate data analysis. 7th ed. Pearson Education, Harlow, Essex, UK.

Kaimowitz, D., and A. Angelsen. 1998. Economic models of tropical deforestation: a review. Center of International Forestry Research (CIFOR), Bogor, Indonesia.

Lambin, E. F., B. L. Turner, H. J. Geist, S. B. Agbola, A. Angelsen, J. W. Bruce, O. T. Coomes, R. Dirzo, G. Fischer, C. Folke, P. S. George, K. Homewood, J. Imbernon, R. Leemans, X. Li, E. F. Moran, M. Mortimore, P. S. Ramakrishnan, J. F. Richards, H. Skånes, W. Steffen, G. D. Stone, U. Svedin, T. A. Veldkamp, C. Vogel, and J. Xu. 2001. The causes of land-use and land-cover change: moving beyond the myths. Global Environmental Change 11(4):261-269. http://dx.doi.org/10.1016/S0959-3780(01)00007-3

Leblois, A., O. Damette, and J. Wolfersberger. 2017. What has driven deforestation in developing countries since the 2000s? Evidence from new remote-sensing data. World Development 92:82-102. http://dx.doi.org/10.1016/j.worlddev.2016.11.012

Lynne, G. D., J. S. Shonkwiler, and L. R. Rola. 1988. Attitudes and farmer conservation behavior. American Journal of Agricultural Economics 70(1):12-19. http://dx.doi.org/10.2307/1241971

Mayer, F., and G. Gereffi. 2010. Regulation and economic globalization: prospects and limits of private governance. Business and Politics 12(3):1-25.

Meyfroidt, P., E. F. Lambin, K.-H. Erb, and T. W. Hertel. 2013. Globalization of land use: distant drivers of land change and geographic displacement of land use. Current Opinion in Environmental Sustainability 5(5):438-444. http://dx.doi.org/10.1016/ j.cosust.2013.04.003

Moller, A. C., R. M. Ryan, and E. L. Deci. 2006. Selfdetermination theory and public policy: improving the quality of consumer decisions without using coercion. Journal of Public Policy and Marketing 25(1):104-116. https://doi.org/10.1509/ jppm.25.1.104

Moros, L., M. A. Vélez, and E. Corbera. 2017. Payments for ecosystem services and motivational crowding in Colombia's Amazon Piedmont. Ecological Economics, in press. http://dx.doi. org/10.1016/j.ecolecon.2017.11.032

Narloch, U., U. Pascual, and A. G. Drucker. 2012. Collective action dynamics under external rewards: experimental insights from Andean farming communities. World Development 40 (10):2096-2107. http://dx.doi.org/10.1016/j.worlddev.2012.03.014
Pelletier, L. G., K. M. Tuson, I. Green-Demers, K. Noels, and A. M. Beaton. 1998. Why are you doing things for the environment? The motivation toward the environment scale (MTES). Journal of Applied Social Psychology 28(5):437-468. http://dx.doi. org/10.1111/j.1559-1816.1998.tb01714.X

Pfaff, A. S. P. 1999. What drives deforestation in the Brazilian Amazon? Evidence from satellite and socioeconomic data. Journal of Environmental Economics and Management 37 (1):26-43.

Phalan, B., M. Onial, A. Balmford, and R. E. Green. 2011. Reconciling food production and biodiversity conservation: land sharing and land sparing compared. Science 333(6047):1289-1291. http://dx.doi.org/10.1126/science. 1208742

Phelps, J., L. R. Carrasco, E. L. Webb, L. P. Koh, and U. Pascual. 2013. Agricultural intensification escalates future conservation costs. Proceedings of the National Academy of Sciences of the United States of America 110(19):7601-7606. http://dx.doi. org/10.1073/pnas.1220070110

Price, J. C., and Z. Leviston. 2014. Predicting pro-environmental agricultural practices: the social, psychological and contextual influences on land management. Journal of Rural Studies 34:65-78. http://dx.doi.org/10.1016/j.jrurstud.2013.10.001

Rico García-Amado, L., M. Ruiz Pérez, and S. Barrasa García. 2013. Motivation for conservation: assessing integrated conservation and development projects and payments for environmental services in La Sepultura Biosphere Reserve, Chiapas, Mexico. Ecological Economics 89:92-100. http://dx.doi. org/10.1016/j.ecolecon.2013.02.002

Robalino, J. A., and A. Pfaff. 2012. Contagious development: neighbor interactions in deforestation. Journal of Development Economics 97(2):427-436. http://dx.doi.org/10.1016/j.jdeveco.2011.06.003

Robinson, B. E., M. B. Holland, and L. Naughton-Treves. 2014. Does secure land tenure save forests? A meta-analysis of the relationship between land tenure and tropical deforestation. Global Environmental Change 29:281-293. $\underline{\text { http://dx.doi. }}$ org/10.1016/j.gloenvcha.2013.05.012

Rode, J., E. Gómez-Baggethun, and T. Krause. 2015. Motivation crowding by economic incentives in conservation policy: a review of the empirical evidence. Ecological Economics 117:270-282. http://dx.doi.org/10.1016/j.ecolecon.2014.11.019

Rudel, T. K., R. Defries, G. P. Asner, and W. F. Laurance. 2009. Changing drivers of deforestation and new opportunities for conservation. Conservation Biology 23(6):1396-1405. http://dx. doi.org/10.1111/j.1523-1739.2009.01332.X

Rudel, T., and J. Roper. 1997. The paths to rain forest destruction: crossnational patterns of tropical deforestation, 1975-1990. World Development 25(1):53-65. http://dx.doi.org/10.1016/ $\underline{\mathrm{S} 0305-750 \mathrm{X}(96) 00086-1}$

Ruiz-Mallén, I., C. Schunko, E. Corbera, M. Rös, and V. ReyesGarcía. 2015. Meanings, drivers, and motivations for communitybased conservation in Latin America. Ecology and Society 20 (3):33. http://dx.doi.org/10.5751/ES-07733-200333

Ryan, R. M., and E. L. Deci. 2000. Intrinsic and extrinsic motivations: classic definitions and new directions. Contemporary 
Educational Psychology 25(1):54-67. http://dx.doi.org/10.1006/ ceps. 1999.1020

Ryan, R. L., D. L. Erickson, and R. De Young. 2003. Farmers' motivations for adopting conservation practices along riparian zones in a mid-western agricultural watershed. Journal of Environmental Planning and Management 46(1):19-37. http://dx. doi.org/10.1080/713676702

Salk, C., M.-C. Lopez, and G. Wong. 2017. Simple incentives and group dependence for successful payments for ecosystem services programs: evidence from an experimental game in rural Lao PDR. Conservation Letters 10(4):414-421. http://dx.doi.org/10.1111/ $\underline{\text { conl. } 12277}$

Souto, T., J. L. Deichmann, C. Núñez, and A. Alonso. 2014. Classifying conservation targets based on the origin of motivation: implications over the success of community-based conservation projects. Biodiversity and Conservation 23 (5):1331-1337. http://dx.doi.org/10.1007/s10531-014-0659-9

Steg, L., and C. Vlek. 2009. Encouraging pro-environmental behaviour: an integrative review and research agenda. Journal of Environmental Psychology 29(3):309-317. http://dx.doi.org/10.1016/ j.jenvp.2008.10.004

Stern, P. C. 2000. New environmental theories: toward a coherent theory of environmentally significant behavior. Journal of Social Issues 56(3):407-424. http://dx.doi.org/10.1111/0022-4537.00175

Turner, B. L., II, E. F. Lambin, and A. Reenberg. 2007. The emergence of land change science for global environmental change and sustainability. Proceedings of the National Academy of Sciences of the United States of America 104(52):20666-20671. http://dx.doi.org/10.1073/pnas.0704119104

Vásquez, T. 2015. Territorios, conflicto armado y política en el Caquetá: 1900-2010. Facultad de Ciencias Sociales, Universidad de los Andes, Bogotá, Colombia.

Vélez, M. A., X. Rueda, L. Moros, A. Link, A. Guerrero, and J. S. Rodríguez. 2016. Paisajes productivos sostenibles: Diseño de un sistema de incentivos para la conservación en el piedemonte Amazónico. Universidad de los Andes and Patrimonio Natural, Bogotá, Colombia. 
APPENDIX 1. Questionnaire in Spanish (presented in the same order as Table 2)

Biophysical and productive characteristics of the farm and productive uses of the land

¿Cuál es el tamaño de este predio?

¿Tiene café? (SI o NO)

¿Qué área tiene de café?

unidades

¿A quién le vende el café?

¿Tiene caña? (SI o NO)

¿Qué área tiene de caña?

¿Tiene pastos? (SI o NO)

¿Qué área tiene de pastos?

¿Tiene otros cultivos? (SI o NO)

¿Qué área tiene de otros cultivos?

¿Tiene bosque? (SI o NO)

¿Qué área tiene de bosque?

¿Tiene rastrojo? (SI o NO)

¿Qué área tiene de rastrojo?

¿Tiene ganado? (SI o NO)

¿Cuántas cabezas?

Socioeconomic characteristics of the household

¿Hace cuántos años vive en esta finca?

¿Cuál es la situación legal de ESTE predio? (Escoger una)

- Tiene escritura y ESTÁ registrada en la oficina de registro

- Tiene escritura pero NO está registrada en la oficina de registro

- Tiene escritura pero NO SE si está registrada en la oficina de registro

- Tiene escritura pero está en proceso de sucesión

- Tiene promesa o papeles de compraventa pero no hay escritura

- Tiene posesión pero NO se tiene papeles

¿Hasta qué año estudió?

¿Cuál es su edad? 
¿Me puede decir cuántas personas viven en esta finca?

Para cada persona que vive en la finca preguntar:

Sexo

Edad

¿Hasta qué año estudió?

¿Cuánto es el ingreso de su hogar mensualmente? (Mencionar que el hogar es la gente que vive en su casa y que el ingreso del hogar es la suma de todos los ingresos que puedan tener los miembros del hogar)

¿Le gustaría que sus hijos se dedicaran a las labores del campo? (si ya tienen una profesión: ¿Le hubiera gustado?)

\section{Social capital and social networks}

¿Usted es miembro de alguna organización o asociación productiva? ( SI, NO, ¿Cuál?)

Usted diría que la gente de esta vereda:

- Se ayudan mucho

- Se ayudan poco

- No se ayudan

\section{Income sources}

¿Qué cultivo le genera más ingresos a su hogar? (Seleccionar uno)

- Café

- Caña

- Otro

- Ninguno

¿Cuáles de estas actividades fueron fuentes de ingreso para su hogar en el último año? [Marcar solo las opciones que fueron fuente de ingreso]

- Cultivos en mi predio para vender

- Madera o leña en mi predio para vender

- Madera o leña del bosque por fuera de mi predio para vender

- Ganado en mi predio

- Trabajo de jornalero en actividades agrícolas

- Por cuenta propia: construcción/industria/comercio/servicios

- Por salarios en construcción/servicios domésticos/industria/comercio/servicios/gobierno/educación

- Pensiones

- Plata que le mandan familiares o amigos desde afuera del país 
- Programas del gobierno

- Otros

\section{Motivations}

Le voy a leer unas frases. Le pido que por favor me diga si está de acuerdo con esa frase usando la siguiente escala: 1 es NO, 2 es UN POCO, 3 es SI, DE ACUERDO, 4 es TOTALMENTE DE ACUERDO.

Disfruto cuando no tumbo el bosque

Soy del tipo de gente que no tumba el bosque

Me arrepiento si tumbo el bosque

Me siento culpable si tumbo el bosque

La gente más cercana a mí se molestaría conmigo si tumbo el bosque

Mis vecinos me criticarían si tumbo el bosque

Yo cuido el bosque SOLO si me pagan por hacerlo

Yo no tumbo el bosque por miedo a las multas que me pueda poner la autoridad ambiental

No veo qué puedo ganar conservando el bosque

\section{Deforestation behavior}

¿Usted o alguien de su hogar ha tumbado bosque desde que llegó a su predio? (SI o NO) 